Vol. 6, No. 1, 2020

Olga Mykhaylyshyn ${ }^{1}$, Pavlo Benediuk ${ }^{2}$

\title{
BETWEEN TRADITIONALISM AND AVANT-GARDE: CREATIVE HERITAGE OF ARCHITECTOR SERHIY TYMOSHENKO IN THE INTERWAR PERIOD
}

\author{
${ }^{1}$ Department of Architecture and Environmental Design, \\ National University of Water and Environmental Engineering, Rivne \\ e-mail: o.1.mykhaylyshyn@nuwm.edu.ua \\ orcid: 0000-0003-3046-7923 \\ ${ }^{2}$ Department of Architecture and Environmental Design, \\ National University of Water and Environmental Engineering, Rivne \\ e-mail: p.o.benediuk@nuwm.edu.ua \\ orcid: 0000-0001-8788-3536
}

Received: 09.05.2020 / Revised: 19.06.2020 / Accepted: 21.06 .2020

(C) Mykhaylyshyn O., Benediuk P., 2020

https://doi.org/10.23939/as2020.01.059

Abstract. The architectural activity of Serhiy Tymoshenko during the interwar period is considered in the article. Based on revealed archive sources the typology of buildings, designed by him, is defined, the authorship of separate dwelling houses and religious buildings is ascertained, the peculiarities of the creative approach to their design are analyzed. On the example of specific buildings the evolution of architectural-stylistic and volume-planning solutions in the context of modernistic tendencies in the development of architecture in the interwar period, the author's notion about the implementation methods of the national idea in architecture, based on the synthesis of traditional and new morphology, is reflected.

Key words: architecture, S. Tymoshenko, interwar period, Ukraine, Lviv, Luck, Wolhynia.

\section{Problem statement}

The particular interest to the researchers of the architectural heritage in Ukraine is the personalities of architects, who with their creativity determined the development of architecture at the turning stages of history, reflecting the complexity and contradictions of their time. Particularly dynamic in this context is the first third of the 20th century, when several stylistic trends were simultaneously established and developed in Ukrainian architecture: national style - Ukrainian architectural modern style, which occupied its historical niche after the rationalism of the end of the 19th century, and avant-garde architecture - one of the stages of the modernism development in the 20th century.

The creative activity of a prominent Ukrainian architect, politician, and public figure Serhiy Tymoshenko (1881-1950) developed at the crossroads of the times. The creative and social activity of this eminent specialist, one of the founders of the school of Ukrainian architectural modernism, was directly proportional to the tension and dynamics of the events that took place in Ukraine in the first decades of the last century. Work in Kharkiv, Kyiv, and exile Lviv, Padebrad (Czech Republic), Lutsk, and later in the United States, as well as enormous practical experience and versatility in the professional field, have yielded enormous results. Dozens of high-quality real estate projects are valuable architectural assets of cities and communities in Ukraine, the USA, and Canada. 


\section{Analysis of recent research and publications}

The first comprehensive studies of S. Tymoshenko's architectural activity were carried out in the monograph and articles of a famous Ukrainian architecture expert V. Chepelyk. The analytical and factual material published in these papers became the starting point for the establishment of a list of objects created during the interwar period. In the 2000s, interest in S. Tymoshenko's personality in the context of his socio-political activity increased significantly. V. Vlasenko and R. Davidyuk devoted their works to the study of his life, social and pedagogical work, in which the authors give a brief discussion of his interwar architectural practice.

Today, the Kharkiv and Kyiv periods of architect's creative work and the Lviv and Volyn periods, which cover his work in the 1920s and 1930s, are well-researched. A lot of information can be found in the articles published for the scientific seminar dedicated to the 130th anniversary of the architect's birth (Rivne, 2011). In particular, the publication of S. Linda and $\mathrm{Yu}$. Bogdanova explores the architectural and social activities of Serhiy Tymoshenko in Lviv; an article by O. Mykhaylyshyn and P. Benediuk presents an analysis of his work in the Volyn period; the articles by P. Rychkov, V. Slobodyan, O. Smolinska consider the architectural features of temples designed by S. Tymoshenko.

A significant contribution to the study of the creative portrait of the architect was made by D. Vitchenko, who examines his ideas on the formation of Ukrainian architectural style in the context of the Kharkiv school of Ukrainian architectural modern style of the early 20th century. Of special importance is the article by P. Benediuk, which explores little known objects of S. Tymoshenko's authorship, located in the Kuban, the territory of modern Russia.

\section{Objective of the article}

The article aims to form a comprehensive understanding of S.Tymoshenko's creative activity in the interwar period in the context of traditionalist and modernist ideas of 1920-30s taking into account newly found and unknown documents and projects.

\section{Results and discussions}

Among the well-known general facts about S. Tymoshenko's biography is the beginning of his career: obtaining a professional education at the Institute of Civil Engineers in St. Petersburg in 1907 (Chepelyk, 1991, pp. 37-41; CSIA SPb, f. 184, op. 3, d. 3447). Even in his student years, Tymoshenko expressed interest in the motives of Ukrainian folk architecture as a means of national self-identification in the professional environment; actively participated in the social life of Ukrainian student community, was one of the initiators of the establishment of a circle of Ukrainian architecture in 1905, which was officially registered under the name "Hromada" in 1909. A broad interest in the study of folk art and national architectural heritage, especially the iconic monuments of architecture, the introduction, and development of Ukrainian architectural forms in the design and construction of that time became a major part of Tymoshenko's further architectural activity. After graduation, he focused on gaining practical experience. Working by the assignment on the construction of the railway station in Kovel and, at the same time, in the local county council, he had the opportunity to bring to life his vision of the development of architectural style, inextricably linked to the Ukrainian tradition. In 1908, Tymoshenko moved to Kyiv, worked as an engineer in the technical department of the Southwestern Railroad.

The next period of the architect's life is connected with moving to Kharkiv with his family. It can be argued that the Kharkiv period (1909-1918) became one of the most fruitful for him: more than 10 residential and public buildings in Kharkiv (Chepelyk, 1999, pp. 217-219), as well as about forty buildings and structures of railway complexes of the North-Donetsk and Kuban railways, were designed and constructed (Benediuk, 2016, pp. 47-58). The last of the named objects could be identified only through the pronounced author's stylistic manner and brief references in archival documents (DAVO, f. 46, op. 7, p. 2450). Tymoshenko actively participated in architectural competitions. Contest project for the tombstone of the composer M. Lysenko in Kyiv (1913) was the winner and was highly distinguished by a jury for the successful proportions and restrained modernization of the "Ukrainian style". In 1915, S. Tymoshenko participated in the architectural competition 
for the "People's House in the village of Lysvensky county of the Perm province" and received the 4th prize. The project took the form of a restrained rationalist modern style with elements of neoclassicism. These and other well-known projects of the Kharkiv period demonstrate the ability for functional planning and the ability to successfully apply the stylistic features of the forms of Ukrainian architectural modern style - as the basis for forming a regional center of this style.

Besides, Tymoshenko actively participated in the artistic life of Kharkiv. In 1912, he became one of the founders of the Ukrainian Literary and Ethnographic Society named after G. Kvitka-Osnovyanenko, and later, one of the leaders of the Ukrainian Art and Architectural Department of Kharkiv Literary and Art Circle, which popularized Ukrainian art, Ukrainian architectural style, took care of the monuments of antiquity. During 1917-1918, the architect was a member of the faction of the local Council of workers, soldiers and peasants deputies, the chief governor of zemstvo (community self-governance), and a delegate to the All-Ukrainian Congress of Zemstvos, and was a leading member of the Ukrainian Council of Kharkiv region. S. Tymoshenko was a member of the Ukrainian Central Rada and chairman of the Peasant Congress of Slobidska Ukraine (1917), in 1918 - the provincial commissioner of the Kharkiv region. In 1919, S. Tymoshenko worked as a senior inspector of the railways of the Ministry of Roads in Kyiv and headed the Ministry of Roads of the UNR (1919). While in Kyiv, he initiated the creation of the Ukrainian Architectural Institute. In 1920-1921 he was a member of the governments of V. Prokopovich and A. Livitsky (Chepelyk, 1999, pp. 195-210; Vlasenko, 2007, pp. 29-37).

In 1921, after the search of Tymoshenko's apartment in Kharkiv, all materials relating to his workshop along with copies of the projects were seized. Attempts of Professor M. F. Sumtsov to return the documents weren't successful (Vlasenko, 2007, p. 32). The description of the activity of the architect of that period shows the high professionalism, the impressive typological breadth and stylistic uniqueness of the objects - urban complexes, industrial, public, residential, sacral buildings, engineering and railway structures, small architectural forms (CSAHAG, f. 3795, op. 1, d. 581, pp. 36-41).

S. Tymoshenko's active socio-political position and change of political vectors in the country forced S. Tymoshenko and his colleagues (P. Kholodny and V. Sichynsky) to move to Lviv, which at that time was a part of the Second Polish Republic. In Lviv, S. Tymoshenko, P. Kholodny, and V. Sichynsky began active consolidation of Ukrainian art forces, organizing groups, exhibitions, and engaging in publishing activities. Researchers point out that periodicals published in Lviv in the early 1920s, namely the journals Dilo, Hromadskyi Visnyk, and Svoboda, became an important source for the analysis of this period. Thanks to these publications, it became possible to outline the milestones of the creative and public life of S. Tymoshenko and his colleagues in Lviv (Linda, Bogdanova, 2012, p. 256). One of the most significant achievements of their civic activities was the organization of the Circle of Ukrainian Art Workers (GDUM) on December 28, 1921 (Hrom. Visnyk, 1922, p. 6). The principles and ideas of the organization were developed in the activity of the Association of Independent Ukrainian Artists (1931).

The exhibitions organized by GDUM $(1922,1923,1924)$ demonstrated more than 50 different architectural design projects by S. Tymoshenko (GDUM Catalog, 1922, No. 272-286; GDUM Catalog, 1923, No. 272-303). Exhibition catalogs confirm the continuation of S. Tymoshenko's active creative work. Over the years, the architect has completed a large number of projects: sketches of small architectural forms, tombstones, kiosks and pavilions, temples and complexes of public buildings. Many of them were conceptual in nature (only the type of object and its location were determined). Some of them provided a specific name for the owner or contractor. Among the projects found, the project proposal for the construction of the National Museum in Lviv is especially worth mentioning. The main custodian of the museum I. Sventcitsky at different times, since 1918, invited Ukrainian architects V. Pezhansky, R. Gritsay, O. Kharkiv, and S. Tymoshenko to cooperation. It was S. Tymoshenko in 1922, who proposed the complete construction of the museum square in the characteristic modernized forms of the Ukrainian Baroque (Fig. 1). The ideas of building the museum stretched for decades. The last variant was proposed by architect J. Novakowski in 1969 (Posadska, 2006, pp. 6-10). Tymoshenko used his stylistic morphology in many of his other projects. Residential buildings, villas, schools, town halls, and community centers combined the features of Ukrainian modern, baroque, and folk architecture (Figs. 2-3). Characteristic elements determined the peculiarity of the author's style: roofs with spiers and kinks, curved pediments, windows and doors with trapezoid finishes, porches with columns, decor, and ornament on the facades. 
Civil engineering projects have not come to existence. However, the implemented projects of the Greek Catholic and Orthodox churches inscribed Tymoshenko's name in the history of the sacral architecture of Galicia (Figs. 4-6). It was in Lviv that the architect found those architectural solutions and stylistic techniques for his sacral structures that later became unique and made it possible to immediately identify their author. First and foremost, it is the church's dominant top, a dome of exquisite neo-baroque shape with a small cimborio and a crown. In the case where the nave is covered by a high roof with a small crease at the top, it is crowned with the same top on the "blind" cimborio. Another feature of Tymoshenko's sacral structures is the covering of the lateral arms of the cartilaginous plan with lower three-sloped roofs that follow the shape of the roofs of Ukrainian huts. The characteristic elements are three windows in the lateral arms, a non-baroque pediment on the front facade, or on its porch. S. Tymoshenko used these elements in the design of stone (stone and brick) and wooden buildings (Slobodyan, 2012, pp. 295-297). We can distinguish a church in the village of Bronnyky near Rivne, designed in 1923 (built in 1928), which became a universal model of a new Ukrainian temple.

The short two-year Lviv period became very important for S. Tymoshenko. It was then that the architect had all the opportunities and favorable socio-cultural circumstances to develop and implement the idea of national identity in Ukrainian architecture.

1923 to 1930, Tymoshenko was in the Czech Republic and worked at the Ukrainian Academy of Economics in Podebrady as an associate professor, later as a professor, and rector of the Academy since 1927. Scientific and pedagogical activities in the Czech period (teaching architecture and construction art at the Academy and the Studio of Plastic Arts) contributed to new architectural searches (UGA, 1959, pp. 65-68; Prague Studio Group, 1925, p. 14).

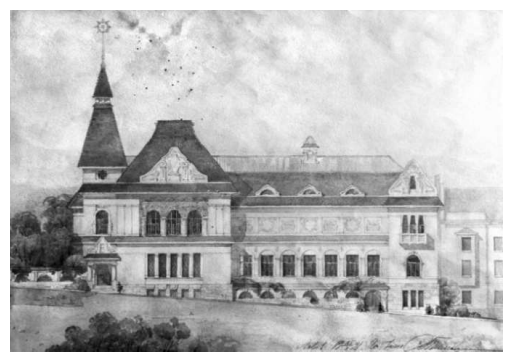

Fig. 1. Projects for the National Museum in Lviv. 1921 (National Museum in Lviv, 1921, Гн-3742)

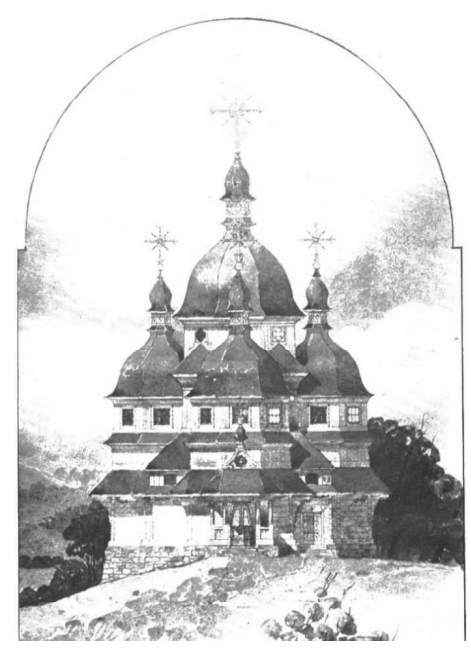

Fig. 4. Project of the Wooden Church near Drohobych, 1920s. (Prague Studio Group, 1925, i1.28)

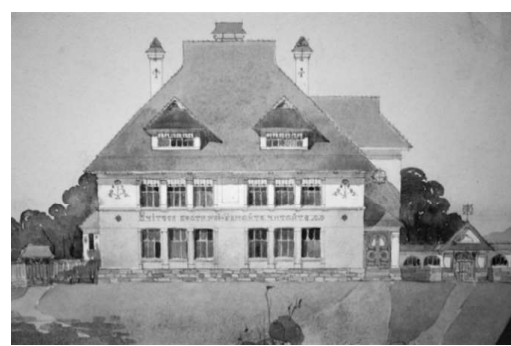

Fig. 2. Rural school project. 1922. (National Museum in Lviv, 1922, Дор - 5645, 25102/2)

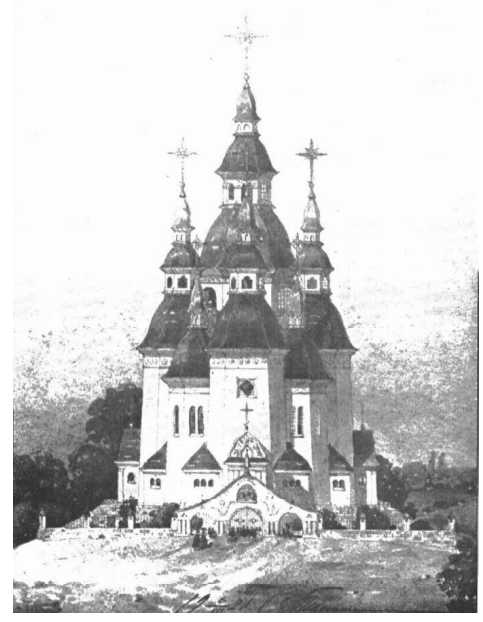

Fig. 5. Project of the Nativity of the Holy Intercession Church, 1921 (Prague Studio Group, 1925, i1.29)

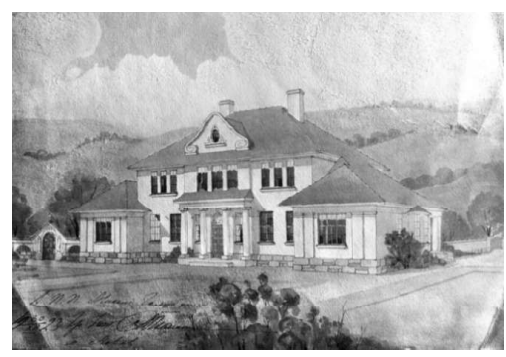

Fig. 3. Project of a House for M. Golubecz', 1923. (National Museum in Lviv, 1923, Гн-1949)

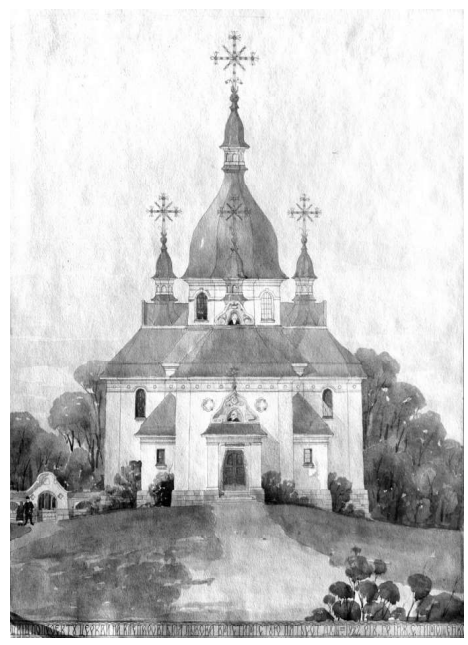

Fig. 6. The project of the church in Kleparov, 1922. (National Museum in Lviv, 1922, Гн-1908)

The next period of Tymoshenko's life was connected with Volhynia. Archival documents show that S. Tymoshenko and his wife Maria obtained Polish citizenship on November 18, 1929 (DAVO, f. 46, op. 7, 
d. 2457, p. 12), and on February 16, 1930, the architect was accepted as the head of the construction department of the District Land Directorate in Lutsk (DAVO, f. 277, op. 1, d. 745, p. 107zv). From April 1934 to August 1935 S. Tymoshenko worked as a clerk of the construction department of the Volyn Voivodeship Administration (DAVO, f. 46, op. 7, d. 2457, pp. 66, 91).

A significant shortage of skilled specialists in the architectural and construction industry of the Volyn Voivodeship was felt throughout the interwar period, which is why the emergence of an experienced architect in the region gave hope for the effective solution of many professional problems, including construction in the field of agriculture. The projects of exemplary farms and vegetable warehouses, developed by S. Tymoshenko during his work at the Directorate, were recommended by the Ministry of Agriculture of the Second Polish Republic for use in all regions of the country. In 1932, for the first time this typical project was used to build a house in the village of Zhydychyn in the Volyn region. The building consisted of three rooms, a kitchen, and a cellar, and was constructed of clay rolls, a traditional material for the construction of folk housing in the central region of Ukraine.

In early 1935, Tymoshenko began his work on the development of three types of individual homes for employees of the Lutsk branch of the Agricultural Bank (DAVO, f.46, op. 7, d. 2457, p. 82).

Together with performing his official duties during this period, the architect carried out many private contracts: projects of individual houses for officials of voivodships and city governments, representatives of intelligentsia and bourgeoisie. Representatives of these social groups most often settled in prestigious areas planned according to new urban planning requirements, where living conditions met all comfort requirements. Reports for Volyn Voivode G. Yuzevsky on the completed design works, concluded by S. Tymoshenko, and preserved drawings certify the fact of designing projects of residential buildings for V. Leshchinsky, M. Kubashevsky, R. Podolsky, D. Grigorovich-Barsky - in Lutsk, for S. Eismund and V. Halkevich in Kremenets (DAVO, p. 46, op. 7, d. 2457, p. 80-81, 83), as well as the objects not mentioned in the reports: mansion for P. Bogdanovich - in Rivne, for T. Serikov - in Kovel, for A. Stanishevska - in Kremenets, for L. Lisitsyna, G. and I. Zavidsky, V. Kurdzhinovsky, A. and V. Tymoschuk, M. Kasprovich, A. and M. Zalesky, L. and J. Tsaruk, and, finally, Tymoshenko's own house, in Lutsk.

It can be assumed that some of these projects became part of the author's exhibit display at the 10th exhibition of the Ukrainian Art Circle "Spokiy" (founded in 1927 by students of the Academy of Arts in Warsaw), which took place in May-June 1937 in Warsaw, Lutsk, Rivne, and Kremenets. In the architectural department of the exhibition, besides Serhiy Tymoshenko, architects Oleksandr Tymoshenko and Leonid Maslov presented their works. The architectural heritage of the experienced master was the largest. S. Tymoshenko presented a retrospective of his own work since 1913, including 15 projects of residential buildings (One reliable life.., 2009, p.162). Among them were several "modern villa projects" (Davydyuk, 2010, p. 232). The projects in the list above allow us to trace the development of the architect's views on the problem of imagery of different types of residential buildings. The development of each project can be considered a creative experiment aimed at rethinking housing as a "small" architectural form, as opposed to previous experience, mainly related to the design of apartment buildings in Kharkiv and Kyiv.

The earliest among the identified ones is the project of a house on the territory of an officer's settlement in Lutsk (1931) (DARO, f.31, op. 1, d. 1791). The tiny building contains only two rooms, an entrance hall, and a kitchen that form a rectangular plan. Two vestibules and a covered terrace are attached to the house. In the decorative design of the arcade and the carvings of the pillars, there is a clear desire to link the architectural solution to the folk tradition of housing in its universal dimension. Here, there are elements of the morphology of the Ukrainian architectural modern style promoted by S. Tymoshenko: a rectangular window on the gable wall is framed by characteristic small columns.

The next projects demonstrate the original synthesis of traditional and new forms. These include the project of a brick house for Volodymyr Kurdzhinovsky in Lutsk (1931) (DAVO, f.158, op. 4, d. 1621) (Fig. 7) and a wooden house for Terentij Serikov in Kovel (1934) (DARO, f. 40, op. 5, d. 76). Despite some time distance, the projects integrate a similar approach to architectural design. In one bundle, parts resembling the traditional Ukrainian house and strict volumes typical of the avant-garde architecture are combined (Fig. 8). A wooden residential house for Pavlo Bogdanovich in the new district of Rivne - Hrabnik (1932) can be considered as transitional from the point of view of stylistics (DARO, f. 31, op. 1, d. 1849) (Fig. 9), where an 
attempt was made to modernize the image by extending the function and applying the forms of constructivism. The integrating elements of a complex asymmetric volume are the horizontals of the eaves and the windows. Plastering the surfaces of wooden walls mimics the stone structure and demonstrates the interpretation of new stylistics in traditional material.

The The first "pure" examples of this approach are the projects of two-store mansions: for Anelia Stanishevska in Kremenets (1933) (DARO, f. 40, op. 6, d. 131) (Fig. 10) and for Dr. Marian Kubashevsky

in Lutsk (1934) (DAVO, f. 158, op. 4, file 2162). The architectural solution is based on a common explicitly functionalist scheme; the facades are distinguished only by some elements (location, shape, and proportions of the individual windows). The volume is arranged around a staircase with a characteristic "constructivist" window (in the form of an elongated rectangle) and a circular "porthole" window. The influence of the style of constructivism is also emphasized by the open brickwork of the porch columns in front of the main entrance, the strict linearity of the metal fencing of balconies and terraces, the cement stucco of the facades.

Because of his election as a senator of the Polish Seim in 1935, Tymoshenko left his office at the Directorate and other institutions of the architectural and construction industry of Volyn. However, he continued with his design practice. The project of a two-store 3-apartment building for Lydia Lisitsyna in Lutsk (1936) (DARO, f. 40, op. 9, d. 124) (Fig. 11) illustrates the further implementation of contemporary architecture ideas in the creative works of S. Tymoshenko. The opening of the volume towards the street space is achieved through the separation of functional blocks - a high parallelepiped staircase and lower cube-shaped blocks of living and utility rooms. The two-store building of doctors Halyna and Irenaeus Zavidsky in Lutsk (1938) (DARO, f.40, op.10, d. 99) (Fig. 12) is an example of the ordinary block building, characteristic of new quarters of the city. The architectural solution attests to the focus solely on the layout of the floors. The accent of the main and yard facades is only the balconies on the second floor, which visually define the axis of symmetry. To ensure the connection between the street and yard space, there is a passage through the ground floor from where one can enter the house. A staircase with a horizontal window - a lantern - is arranged in the volume of a rectangular prism, reminiscent of the techniques of Art Nouveau architecture, hidden here by the asceticism of the external forms.

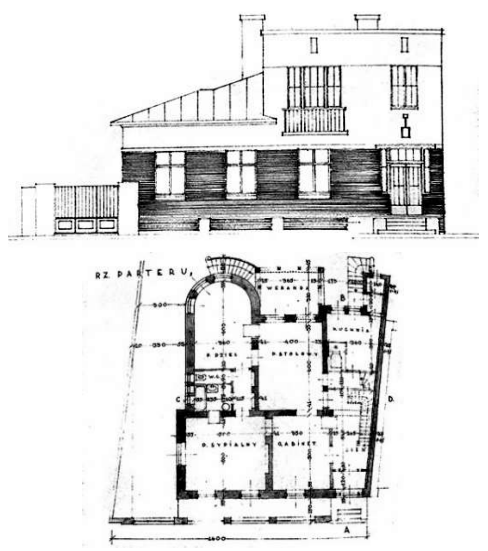

Fig. 7. The project of a house for V. Kurdzhinovsky in Lutsk, 1931. (DAVO, f.158, op.4, d.1621)
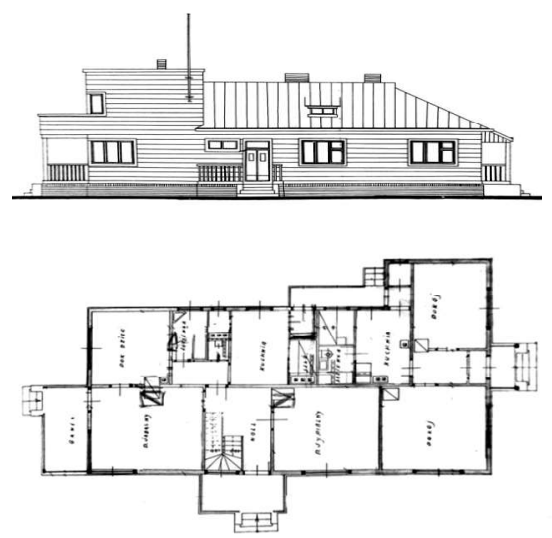

Fig. 8. The project of a house for T. Serikov in Kovel, 1934 p. (DAVO, f.40, op. 5, d. 76). Drawing by P. Benediuk

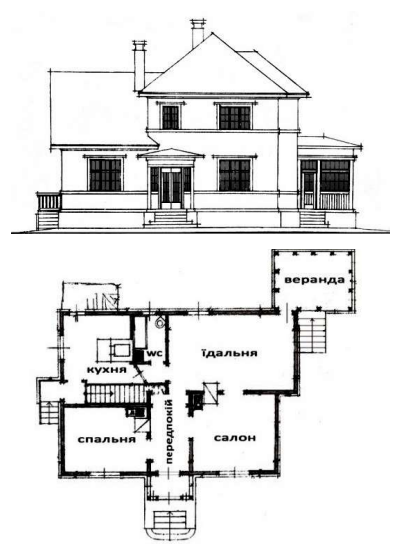

Fig. 9. The project of a house for P. Bogdanovich in Rivne, 1932.

(DARO, f.31, op.1, d. 1849).

Drawing by P. Benediuk

At the site belonging to the Lutsk society "Volt", and later to Anna and Mykola Zalesky, S. Tymoshenko designed a multi-apartment three-store block (DAVO, f. 158, op. 4, d. 2985) - one of the largest in the city at that time. The image of a house located in the center of the city (Kryvy Val Street, 17) near the building of the new post office (1937) synthesized elements of the modernized classicism of the late 1930s (the pilaster side of the main facade resembles an overhead portico), constructivism (decorative pointing of the surfaces of facades 
imitate the structure of large wall blocks) and streamline style (balconies occupy the corner of the house and have a rounded outline) (Fig. 13).

S. Tymoshenko's own house (1938) (16 Yaroshchuk St.) (Fig. 14) and the mansion of Lucia and Yulian Tsaruk (1939) (14 Yaroshchuk St.) (DARO, f. 40, op. 10, d. 170) (Fig. 15) are characterized by maximum laconicism, which tends to be architectural cubism. These objects were the last of the architect's designs during the interwar period.
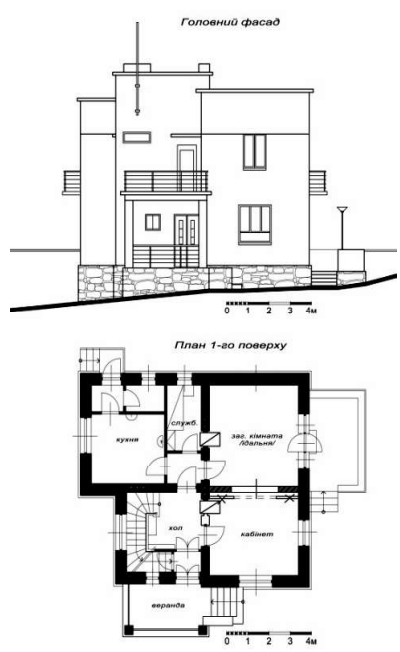

Fig. 10. The project of a house for A. Stanishevska in Kremenets, 1933. (DARO, f.40, op. 6, d.131)

Drawing by P. Benediuk
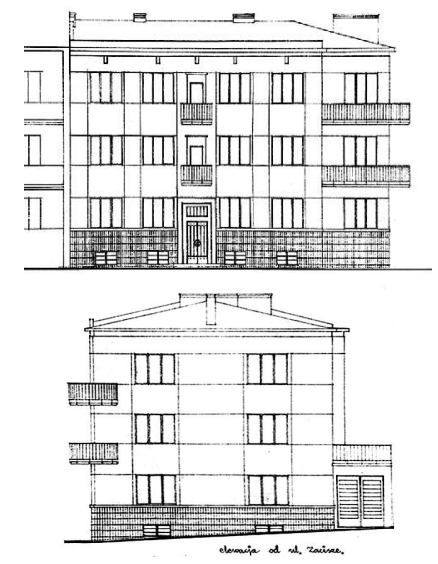

Fig. 13. The project of an apartment building in Lutsk, 1937. (DAVO, f.158, op. 4, d. 2985)

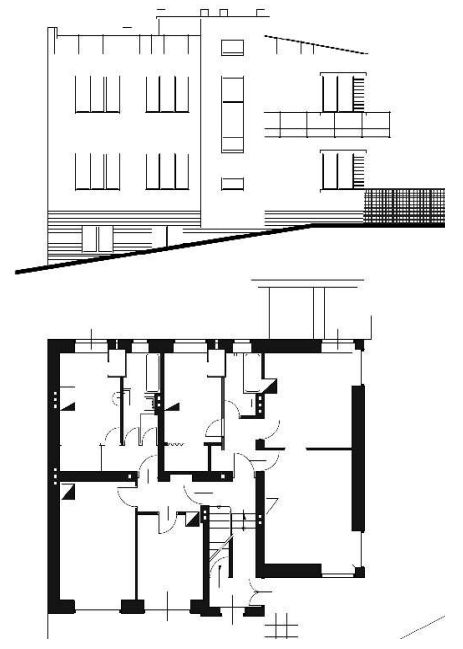

Fig. 11. The project of a house for L. Lisitsyna in Lutsk, 1936. (DARO, f.40, op.9, d.124).

Drawing by P. Benediuk

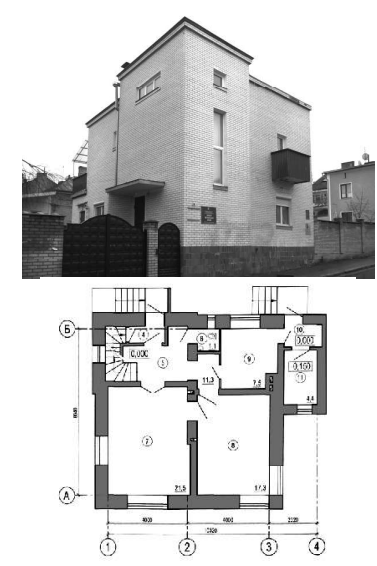

Fig. 14. S. Tymoshenko's house in Lutsk, 1934. Foto and drawing by P. Benediuk

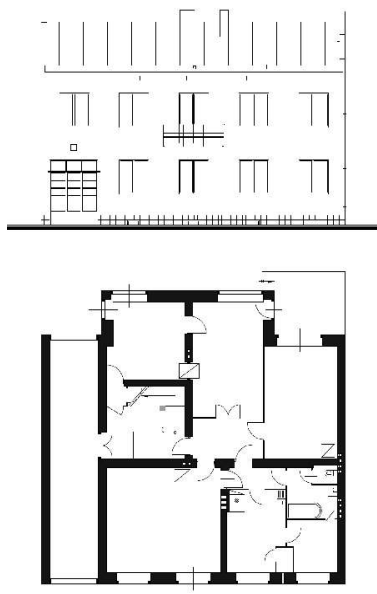

Fig. 12. The project of a house for H. and I. Zavidsky in Lutsk, 1938. (DARO, f.40, op.10, d.99).

Drawing by P. Benediuk

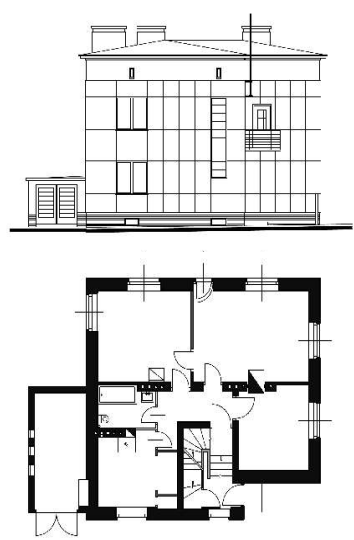

Fig. 15. The project of a house for L. and Ju. Tsaruk in Lutsk, 1938. (DARO, f. 40, op. 10, d.170).

Drawing by P. Benediuk

S. Tymoshenko's creative work in Volyn was not limited to residential buildings. The aforementioned project of a temple for the village of Bronnyky was recognized by Metropolitan of Warsaw and Volyn Dionysius as, from the perspective of the Orthodox Church, the most appropriate representation of the style of an Orthodox church for Volyn and as a model for the design of new shrines (AAN, p. 300). By the end of the 1930s, S. Tymoshenko's architectural heritage had been complemented by five more temples - a wooden one in the village of Kivertsi (now Prylutske) (1934) and Horaymivka (1938), and a brick building in the village of Borovychi (1937) in the Volyn region, built in Yasynynychi (1935) and Oparypsy (1939) in the Rivne region. 
At the blueprint core of Tymoshenko's Volyn churches lies a centric or compact cross-shaped scheme with a short transverse nave and an elongated western part, reminiscent of nine-part wooden shrines of the Dnieper and temples - examples of monumental stone architecture of Ukrainian Baroque era beginning of the XVIII century. Unlike the churches built by the architect in the interwar Galicia, the ninety-part plan of the Volyn temples is small in volume. The one thing that remains unchanged is an altitude composition of volume, dominated by the dome of an exquisite silhouette, completed by a characteristic bell-shaped top on the "blind" lantern. The dynamic plasticity of the silhouettes is reinforced by the same tops mounted above each volume. One characteristic of the architect's creative demeanor is the low-breaking roof and the selection of transitional elements in the completion of temples from the lower tier to the dome drum or to the dome. However, in the context of accentuating the figurative connection with the tradition of Ukrainian temple building, there were noticeable changes in the sign and morphological system: reduction, minimization, or rejection of decorative elements used by the architect in the 1900-20s. Modernist tendencies in the architecture of Tymoshenko's Volyn churches is evident in the accentuated monumentality, massiveness, laconism of the lower part of the volumes, the dry geometry of the columns and the shape of the window openings. The appearance of round windows on the facades, strict "constructivist" horizontal eaves, window sills, and ribbon windows can be considered as a sign of the influence of avant-garde architecture. It should be noted that by modernizing the image of the churches, the architect certainly emphasizes the connection with the archetype - the dwelling house from which each Ukrainian temple originates (expressed in the characteristic form of a church covering a four-sloped roof with a small semi-gable, architectural and decorative design of porches.

\section{Conclusions}

To sum up, it should be noted that the interwar period of Serghiy Tymoshenko's life was marked by high creative activity which was fulfilled in the design of a large number of objects. The vision of the development of national stylistics in the early 1920s, which was based on the interpretation of traditional (folk) and classical (Ukrainian baroque) forms of Ukrainian architecture during the "Lviv" period, underwent a gradual transformation under the influence of external social and creative factors in the years of creative work in Volyn. The change of scale and content of design tasks, in particular with regard to the design of housing in 1921-39, led to the maximum individualization of the creative process, a significant expansion of the range of stylistic landmarks, complementing its formal and compositional techniques of avant-garde architecture, as the time required. The architect focused on church construction, in which he sought to express the national idea and to present visions of the ways of development of new Ukrainian architecture in general. In the 1930s, Halychyna and Volyn, unlike other regions of Ukraine in its present borders, were regions where such searches were possible, and church architecture was perhaps the only creative ground for such activity. S. Tymoshenko's proposal to rethink the traditional image of the Ukrainian temple in the context of the universalization and modernization of architectural forms was seen as one means of emphasizing the connection between Ukrainian and European culture and, at the same time, national identification of the Ukrainian people.

\section{References}

Archiwum Akt Nowych w Warszawie, MWRiOP, sygn.1186.

Benediuk P., 2016. Architecture of the Station Complexes of the North-Donetsk and Kuban Railways in the Creative Work of S. P.Tymoshenko. Suchasni problemy arxitektury ta mistobuduvannya, 43, part. 1, pp. 47-58.

Vitchenko D., 2014. Kharkov Period of Life and Creativity of Sergiy Tymoshenko. Pam 'yatky Ukrayiny, 12, pp. 42-51.

Vlasenko V., 2007. Serhiy Tymoshenko is an Architect and Politician. Sumskyj istoryko-arxivnyj zhurnal, II-III, pp. $29-37$.

Davydiuk R., 2010. Architect in Politics: Social and Political Activities of Serhiy Tymoshenko in the 1930s. Volynski istorychni zapysky, 5, pp. 228-235.

State archive of Volyn region (DAVO). f. 46, op. 7, d. 2457; f. 158, op. 4, d. 1621; f. 158, op. 4, d. 2162; f. 158, op. 4, d. 2895; f. 277, op. 1, d. 745.

State archive of Rivne region (DARO), f. 31, op. 1, d. 1791, 1849; f. 40, op. 5, d. 76; f. 40, op. 6, d. 131; f. 40, op. 9, d. 124; f. 40, op. 10, d. 99, 170 .

Second Ukrainian Art Exhibition: Catalog. GDUM in Lviv, 1923, May, No. 272-303. 
One reliable life ... (to the 100th birthday of Leonid Maslov), 2009. Lutsk.

Linda S., Bohdanova J., 2012. Serhiy Tymoshenko's Architectural and Public Activity in Lviv. Arkhitekturna spadshchyna Volyni, 3, pp. 255-264.

Art Chronicle. 1922. Hromads 'kyy visnyk, 8. Lviv, 26.02. 1922.

Mykhaylyshyn O., Benediuk P., 2012. Modernist tendencies in the S. Tymoshenko's work in the "Volyn" period. Arkhitekturna spadshchyna Volyni, 3, pp. 265-277.

Posadska D., 2006. Projects for the National Museum in Lviv in the 1920s and 1960s. Halyts'ka brama, 5-6 (137-138), pp. 6-10.

Professor Serhiy Tymoshenko. Ukrayins'ka Hospodars'ka Akademiya v Ch.S.R. 1922-1935. New-York, 1959.

Rychkov P., 2012. Church of St. John the Baptist in the village Prylutske: a local episode of the creative biography of architect S. Tymoshenko. Arkhitekturna spadshchyna Volyni, 3, pp. 280-286.

Slobodyan V., 2012. Galician projects of Serhiy Tymoshenko's churches. Arkhitekturna spadshchyna Volyni, 3, pp. 291299.

Smolinska O., 2012. Architecture of the Intercession Church in Bronniki: a tribute to tradition and an innovative search. Arkhitekturna spadshchyna Volyni, 3, pp. 300-304.

Contemporary Ukrainian Art - Prague Studio Group. Prague, 1925. 32 c. [online] Available at: <http://diasporiana.org.ua/ mistetstvo/1258-grupa-prazkoyi-studiyi/> [Accessed 10 March 2020].

Ukrainian art exhibition: Catalog. GDUM in Lviv, 1922. Lviv, №264-286.

Central State Historical Archives in St. Petersburg (CSA StP), f. 184, op. 3, d. 3447.

Central State Archives of Higher Authorities and Governments of Ukraine (CSAHAG), f. 3795, op. 1, d. 581.

Chepelyk V., 1999. Architect S. Tymoshenko, a traditionalist and innovator. Teoriya ta istoriya arkhitektury $i$ mistobuduvannya, 4, pp. 195-210.

Chepelyk V. V., 1991. Enthusiasts of the Ukrainian architectural style of the St. Petersburg Community. Arkhitektura Ukrayiny, 1, c. 37-41.

\author{
Ольга Михайлишин ${ }^{1}$, Павло Бенедюк² \\ ${ }^{1}$ Завідувач кафедри архітектури та середовищного дизайну, \\ Наиіональний університет водного господарства та природокористування, Рівне \\ e-mail: o.l.mykhaylyshyn@nuwm.edu.ua \\ orcid: 0000-0003-3046-7923 \\ ${ }^{2}$ Стариий викладач кафедри архітектури та середовищного дизайну, \\ Національний університет водного господарства та природокористування, Рівне \\ e-mail: p.o.benediuk@nuwm.edu.ua \\ orcid: 0000-0001-8788-3536

\section{МІЖ ТРАДИЦІОНАЛІЗМОМ І АВАНГАРДОМ: ТВОРЧА СПАДЩИНА АРХІТЕКТОРА СЕРГІЯ ТИМОШЕНКА МІЖВОСННОГО ПЕРІОДУ}

\begin{abstract}
Анотація. У статті досліджена архітектурна діяльність Сергія Прокоповича Тимоченка у міжвоєнний період. На основі виявлених авторами архівних джерел окреслено типологію об'єктів архітектора в регіоні, встановлено авторство шодо окремих житлових будинків та культових будівель, проаналізовано особливості творчого підходу до їх проектування. На прикладі конкретних об'єктів показано еволюиію архітектурно-стилістичних та об'ємнопланувальних вирішень в контексті модерністичних тенденцій розвитку архітектури міжвоєнного періоду, уявлень автора про прийоми втілення начіональної ідеї в архітектурі, щуо базуються на синтезі традиџійної і нової морфологї̈.
\end{abstract}

Ключові слова: архітектура, С. Тимоченко, міжвоєнний період, Україна, Львів, Луцьк, Волинь 